Elena Chernikova

Russian Presidential Academy

of National Economy and Public Administration

Russia

ec8064@mail.ru

Maxim Prokoshin

Russian Presidential Academy

of National Economy and Public Administration

Russia

\title{
EFFECTIVE DEVELOPMENT PROCESS OF THE STATE FINANCIAL CONTROL IN RUSSIA
}

\begin{abstract}
The subject of the research is the development process of the state financial control in Russia. The research methodology consisted of a legalistic, analytical methods and a systematic approach.
\end{abstract}

Keywords: state financial control, standards of internal state financial control, interbudgetary transfers, budgetary coercive measures, amounts of illegally used budget funds

\section{Introduction}

The article examines the main and most current trends in the development of the state financial control in the Russian Federation. The main trend is aimed at tightening the state financial control, with the purpose of strengthening financial and budget discipline, and consequently, improving public finances management.

\section{Main part}

Let us consider the main trends in the state financial control development in Russia.

It is proposed to expand the scope of state financial control, namely, to empower state financial control bodies with powers to control the compliance with the provisions of the laws (acts) defining the expenditure obligations of the relevant public law entities, i.e.:

To detail the objects of control, i.e., to give the bodies of external and internal financial control additional powers to effectuate control of budget funds recipients. For example, the Accounts Chamber of the Russian Federation and the Federal Treasury will control subjects of the Russian Federation in the case of interbudgetary transfers, budget credits, other funds provided from the federal budget to the budgets of the subjects, as well as municipalities, in the case of interbudgetary transfers to subjects from the federal budget in order to co-finance the expenditure commitments of the region for providing interbudgetary transfers to the municipalities.

To create effective federal standards system of internal state financial control.

The Russian government will be empowered to approve federal standards of internal state financial control. The creation of federal standards system is aimed at consolidating uniform principles and grounds for exercising control activities, as well as the procedure for pretrial appeal of control bodies acts, internal quality control of state financial control, extension of the period for executing warnings and orders.

In turn, the specifics of the control activities implementation of a specific internal state financial control body 
will be approved by the authorized organ of the relevant public law entity.

The Russian Ministry of Finance approved by its Order of 03.10.2018 N 203n the first standard of internal state financial control - the Standard for implementation of the internal state financial control by the Federal Treasury "Verification of granting subsidies from the federal budget to federal budget and autonomous institutions and (or) their use".

This standard defined the procedure for the formation of a list of major issues to be checked during the verification of subsidies granting from federal budget to federal budgetary and autonomous institutions as well as their use by these institutions, the questions of control implementation of actions during the verification, and also the registration and realization of its results.

The state standards enactment is aimed, among other things, at unifying the regulatory framework of the state financial control system, increasing the control bodies efficiency, introducing risk-oriented approaches in planning their activities and eliminating powers duplication of external and internal state financial control bodies.

The following direction of development is the improvement of implementing procedure of the state financial control results.

This direction will be realized, first of all, through the improvement of applying budgetary coercive measures procedure and formation of warnings and orders issued by the internal state financial control bodies. It should be noted that the application of budgetary coercive measures procedure has already been partially updated. Financial authorities now make decisions not only on the application of budgetary coercive measures or the decision to refuse to apply them, but also decisions on their modification and abolition.

It is proposed to vest the governing bodies of state extra-budgetary funds with the decision-making powers on the application of budgetary coercive measures when using the means of the corresponding state extra-budgetary funds. In turn, it is planned to empower financial bodies with the authority to apply budgetary coercive measures in relation to state extra-budgetary funds, in case of violation by them the spending goals and conditions of interbudgetary transfers provided to them.

It is necessary to note the fact that the problem of the definition of the concept "damage caused to public law entity" is very acute.
Due to the fact that in the Russian legislation this term is not defined, the approaches to calculating the amount of such damage are not defined, this problem was solved in practice as follows.

The Ministry of Finance of the RF in its official letters indicated that the internal state financial control body may qualify the existence of this damage, and also it noted that the compensation for damage caused by the violation of budget legislation should be made by the person who committed this particular violation. The courts, in turn, in the absence of other explanations and specific legal norms, actively used Ministry's position in law enforcement practice, such as for example - the Third Arbitration Court of Appeals Ordinance N 03AП-1240/15 of 04/08/2015, which in turn contributed to the effective resolution of disputes between control authorities and objects of control. Now this approach is completely modified.

The concept of "damage caused to public law entity" will be replaced by the term "amounts of illegally used budget funds", i.e., in fact, the amount of outstanding work, services, undelivered goods, the amount of overstated payments from the budget. In addition, the Ministry of Finance of the Russian Federation will adopt a methodology for calculating the amounts of illegally used budget funds taking into consideration the peculiarities of different types of violations in the financial and budgetary sphere. Further, as a consequence, the term "order" will be updated, where instead of the words "compensation for damage of the corresponding public law entity", will be established the demand to transfer the "amounts of illegally used budget funds" to the corresponding public law entity budget.

Moreover, the deadline for compliance with the order issued by the internal state financial control body will change, it will be possible to extend it, at the request of the head of the control object, but not more than once.

As regards directly the implementation of the financial verifications, for example, with regard to legal entities that are not participants of the budget process, the Budget Code of the RF plans to fix the possibility of conducting separate inspections of such entities, i.e., regardless of checking the budget process participants who provided them with funds from the budget. This manoeuver will help to increase the state financial control efficiency, due to the increase in labour and material resources, as well as the time for conducting an inspection, since the verification of the above legal entities will not be tied to the verification of budget participants who provided these 
entities with funds from the budget, i.e., will be conducted independently.

It should be emphasized that the introduction of new concepts, standards, and a general tightening of the state financial control will further strengthen financial and budgetary discipline and, as a consequence, increase public finance management efficiency.

We note the fact that development is necessary, not only for the state financial control which is conducted by special state financial control bodies, but also for the improvement of internal (departmental) financial control organization process and its interaction with state financial control. The task is to harmonize state financial control and internal (departmental) financial control, so that these types of control will mutually effectively complement each other.

First of all, the bulk of violations should be revealed, precisely within the framework of control measures realizing by internal (departmental) financial control, and state financial control should serve as a kind of a follow-up control. This combination will eliminate duplication of verification on the same issues and periods of activity. As a result, the burden on the Accounts Chamber of the Russian Federation, the Federal Treasury, control and accounting organs and internal state financial control bodies of subjects of the Russian Federation will decrease, and consequently an increase in their personnel potential will follow, which in turn will generally affect the state financial control bodies efficiency.

In the future, in order to reduce the burden on state financial control bodies, it is planned not to indicate in warnings and orders issued by these organs the information on violations of the Russian Federation budget legislation identified by budget process participants during effectuation of departmental control, subject to the availability of measures taken to eliminate them. Accordingly, the bulk of violations will have to be detected inside the state agencies, and materials, in the absence of measures taken to eliminate violations or signs of crime, will be sent to the financial control authorities, law enforcement agencies and the courts, directly, in order to bring the perpetrators to the relevant types of responsibility.

\section{Conclusion}

In conclusion, it should be noted that there is a high potential of the identified trends in improving the state financial control system. In order to increase the state financial control effectiveness, a conclusion was drawn that it needs further tightening, improvement of the regulatory framework for its successful implementation, and harmonization with internal (departmental) financial control.

Strict state financial control is the key to the efficient budget spending and as a result to the increase in the level of financial, economic and national security of the Russian Federation. The given position had already been expressed by E.V. Chernikova in her previous works: "National security and economic security as its component are directly related to the process of development, distribution and use of funds ... we can determine financial security as an element of economic and national security notions" [Chernikova 2010, p. 39].

The findings can be used in further research on the state financial control development in Russia.

\section{Bibliography}

Chernikova E., Vysotskaya O. (2010), Financial security as an element of the state national security system, "Law" no. 7.

\section{Legal Acts}

Constitution of the Russian Federation of 1993 (Journals of Laws N 237).

Federal Law of 19.07.2018 "On Amendments to the Budget Code of the Russian Federation" and Article 4 of the Federal Law "On Amendments to the Budget Code of the Russian Federation and Recognizing Certain Provisions of Legislative Acts of the Russian Federation" (Journals of Laws N 222-FZ).

The Budget Code of the Russian Federation of 31.08.1998 (Journals of Laws No. 145-FZ).

Resolution of the Government of the Russian Federation of 15 April 2014, "On Approval of the State Program of the Russian Federation Management of Public Finances and Regulation of Financial Markets" (Journals of Laws No. 320).

Resolution of the Third Arbitration Court of Appeal dated 8 of April 2015 (Journals of Laws No. 03AP-1240/15).

Decree of the Government of the Russian Federation of 30 December 2013 "On the Program for Improving the Efficiency of Managing Public (State and Municipal) Finances for the Period until 2018" (Journals of Laws No. 2593-p). 
Order of the Ministry of Finance of Russia of 03.10.2018 "On Approval of the Standard for the Federal Treasury to Implement Internal State Financial Control" Verification of the provision from the federal budget of subsidies to federal budget and autonomous institutions and / or their use (Journals of Laws N 203n).

Draft federal law "On Amendments to the Budget Code of the Russian Federation in terms of improving state (municipal) financial control, internal financial control and internal financial audit", adopted on 1 reading of 19.09.2018 (Journals of Laws N 493988-7).

Official Letter of the Ministry of Finance of the Russian Federation of 29 December 2014, "On compensation for damage to a constituent entity of the Russian Federation caused by a violation of the budget legislation of the Russian Federation and other regulatory legal acts regulating budget legal relations" (N 02-01-10 / 68389).

Official Letter of the Ministry of Finance of the Russian Federation of 14 July 2014 "On the requirements contained in the orders of the bodies of state (municipal) financial control" (N 02-10-09 / 34216).

\section{Authors biographies}

Elena Chernikova - Professor, Doctor of Law, Candidate of Economics. Head of Department of Legal Regulation of Economy and Finance Institute of Public Administration and Management of the Russian Presidential Academy of National Economy and Public Administration. Research topics: Financial Law, Comparative Law, Judicial Power \& Legal Procedures. Author of more than 200 scientific publications in Russian and English. Member of Centre for Information and Research Organisation in Public Finance and Tax Law in the Countries of Central and Eastern Europe. Member of International Association of Financial Law (Russia).

Maxim Prokoshin - Candidate of Sciences, Docent of the Department of Legal Regulation of Economy and Finances Institute of Public Administration and Management of the Russian Presidential Academy of National Economy and Public Administration. Member of the Centre for Information and Research Organisation in the Public Finance and Tax Law in the Countries of Central and Eastern Europe. Research topics: Tax law, Budget law, Business law, Comparative Law. Author of more than 43 scientific publications in Russian and English. 